\title{
質問票調査における音響環境調整の効果に関する実験的研究
}

一内田クレペリン精神検査への背景音楽の影響—

梶山 祥子* 佐久間祐子** 松井 研一** 土屋 英俊**

\section{Effects of Background Music on the Uchida-Kraepelin Test}

\author{
Yoshiko KAJIYAMA*, Yuko SAKUMA**, Kenichi MATSUI** \\ and Hidetoshi TSUCHIYA**
}

The possible effects of background music on the Uchida-Kraepelin Test, or a continuous adding performance test, were investigated. Subjects were 56 female college students who were devided into 3 groups. Each group performed the UchidaKraepelin Test under different conditions; stimulative music and control (Stimulative Group), sedative music and control (Sedative Group), white noise and control (White Noise Group).

Major findings are summarized as follows,

1. There was no discernable difference in the effects the 3 types of back ground sounds had on the quantity aspect of additioning performance.

2. In stimulative group and white noise group, the error was lower in the control (no sound) comparing with sedative group; probably due to learning effects.

3. Sedative music might have a decreasing effect on errors.

Key words : Uchida-Kraepelin Test, background music, white noise 内田クレペリン精神検査, 背景音楽, ホワイトノイズ

\section{I 緒 言}

健康と愁訴に関する質問票調査を行う際の環境 条件として, 従来は騷音を排除することが重視さ れてきたが，完全に排除することができない偶発 的な騒音の影響についてなお問題が残されてお り，かりに完全に騒音を遮断することができたと しても，非日常的な環境によって生ずる心理的圧 迫感が増強されることによる調査成績への影響が
生ずると考えられる。そこで本研究は逆に背景音 楽を積極的に負荷して, 偶発的な騒音の影響を小 さくすることによって，このような質問票調査結 果を安定化できるかどうかを検証することを目的 として, 背景音を負荷して質問票調査を行う一連 の実験（佐久間ほか，1996）を行った。本論文で は, 音楽負荷が内田クレペリン精神検査に及ぼす 影響を調べるために行った実験について報告す る.内田クレペリン精神検查は, 性格検査として

$*$ 東邦大学医療短期大学

** 東邦大学医学部公衆衛生学教室

* College of Health Professions, Toho University

** Department of Public Health, Toho University 
用いられているものであるが，他の検査法や質問 粽が言語による回答に便宜的に点数を与えて結果 を得るのに対し，加算作業の個数と誤謬の個数と いうはっきりとした数值で結果を得ることができ る（中塚，1991）利点があり, 諸研究 (IWATA, 1975，大場ほか，1976，1978a，1978b，1979，川 畑ほか，1980，山内ほか，1989）において課題作 業として用いられていることから，本実験におけ る質問票として用いた。負荷する背景音としては， 刺激的音楽，鎮静的音楽およびホワイトノイズを 用いた。

\section{II 方 法}

\section{1. 実験計画}

1）被験者

被験者は東京都内にある $\mathrm{T}$ 短期大学 1,2 年の 女子のうち実験に参加することを承諾した 64 名 で，これをランダムに22名，21名，21名の 3 実験 群に分けた。

\section{2）実験期間および奉験場所}

実験は，1992年10月から1993年 1 月の期間に実 験群別に行い，カリキュラムの時間割の違いによ る影剴を避けるために，同一矅日，同一時刻（放 課後）を赛験日時として実験を行った。実験場所 は T大学医学部心理学実習室とした。

3）質問票

質問票として内田クレペリン精神検査を用い た. 本検查は 1 桁の数字の単純加算であり，5分 間の休咊を挟んで，前半15分間，後半15分間の各 1 分ごとの作業量をグラフ化して作業曲線をみる ものである．結果を直接的に数值として得られる
という前述の理由の他, 信頼性, 妥当性の検討が 既になされ，標準化されているとの見地から採用 した.

4）背景音

刺激的音楽，鎮静的音楽とホワイトノイズの 3 種類を使用した。刺激的音楽と鎮静的音楽は，音 楽療法の分野で以下のように定義されている（E， Radocy/J.D. Boyle，1985，野辺地，1990)．1）音 の高さ：周波数が高いものが刺激的，低いものが 鎮静的，2）音の強さ：大きな音，および音の強さ の変化が大きいものが刺激的, 音量が大きくなく, 音の強さの変化が緩やかなものは鎮静的．3）音 色：聴いていて元気が出る，あるいは活気づけら れるような音楽は刺激的４４）メロディと八ーモ ニーを作る音程：音程の上下の変化が大きく，ス タッカートのついたものや厚みのあるハーモニー を伴う旋律は刺激的，単調で美しいメロディ，不 協和音のないものは鎮静的.5）リズムとテンポ： リズムの早いもの，テンポの早いもの，アクセン トのはっきりしたものは刺激的, 単調で強さに大 きな変化のないものは鎮静的。

これらの定義に基づき, バイオミュージック学 会事務局長田中正道氏に依頼して曲目を選曲（表 1), その中から上述の各々の定義に適合する部分 を選択して, 各々前半15分後半15分計30分間ずつ に編集録音した 2 種類のテープを用いた。

5）実験に用いた音響器具

音響器具としては, $\mathrm{CD}$ ラジオカセットテープ レコーダー (SONY-CFD-K10), 赤外線方式コー ドレスヘッドフォンシステム（SONY-MDRIF710K)，コードレスヘッドフォン（SONY-

表 1 背景音楽の曲目

\begin{tabular}{|c|c|}
\hline 刺激的音楽 & 鎮静的音楽 \\
\hline 花のワルツ(ショパン) & アラベスク/ドビュッシー \\
\hline ディベルティメント・1/モーツアルト & アリオーソ/バッハ \\
\hline アイネクライネナハトムジーク/モーツアルト & パヴァーヌ/フォーレ \\
\hline ドナウ川のさざ波/イバノビチ & オンブラ・マイ・フ/ヘンデル \\
\hline トリッチ・トラッチ・ポルカ/J.シュトラウス & シェヘラザード/リムスキー・コルサコフ \\
\hline 皇帝问舞曲/J.シュトラウス & フルートとハープのための協淡曲/モーツアルト \\
\hline 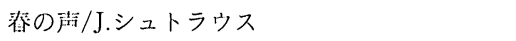 & ピアノ協姿曲 K. 467/モーツアルト \\
\hline
\end{tabular}


MDR-IF710）を用いた.

6）実験デザイン

実験デザインは表 2 に示すとおりで, 被験者を 3 群に分け，それぞれコードレスヘッドフォンを 装着して, 刺激的音楽, 鎮静的音楽, あるいはホ ワイトノイズを負荷した。対照実験（コントロー ル）はヘッドフォンを装着し無音の条件の下で内 田クレペリン精神検查を行った. 3 群とも第 1 回 目を背景音負荷実験，第 2 回目を対照実験とし, 実験間隔は 1 週間以上とした。

\section{2. 実験方法}

1）実験の手順

実験は, 次の手順で行った(図 1 )。まず, (1)へッ ドフォンの使用方法の説明, 次に, (2)内田クレペ リン精神検查施行方法の説明を行い, (3)へッド フォンを装着, (4)背景音負荷を開始し, 40秒後に, (5)内田クレペリン精神検査を 2 分間の練習の後, 前半を開始，615分後に背景音負荷終了して，(7) 前半の作業を終了, ヘッドフォンをはずす. (8) 5 分間の休憩（各自着席のままへッドフォンをはず す）後，(9)再びヘッドフォンを装着し，前半と同 様の手順で後半15分の作業を行う.

2）背景音の負荷方法と音量の調節

表 2 実験デザイン

\begin{tabular}{l|cccccc}
\hline 群 & $\begin{array}{c}\text { 刺激的音楽群 } \\
(\mathrm{N}=16)\end{array}$ & $\begin{array}{c}\text { 鎮静的音楽群 } \\
(\mathrm{N}=19)\end{array}$ & $\begin{array}{c}\text { ホワイトイイズ群 } \\
\text { 群 }(\mathrm{N}=21)\end{array}$ \\
\hline 回 & 1 回目 & 2 回目 & 1 回目 & 2 回目 & 1 回目 & 2 回目 \\
\hline 実験 & 負荷 & $\mathrm{CTL}$ & 負荷 & $\mathrm{CTL}$ & 負荷 & $\mathrm{CTL}$ \\
\hline 質問票 & \multicolumn{5}{|c}{ 内田クレペリン精神検査 } \\
\hline
\end{tabular}

\begin{tabular}{|c|c|c|}
\hline $\begin{array}{l}40 \\
\text { 秒 }\end{array}$ & 前半15分 5 & 後半15分 \\
\hline $\begin{array}{l}\text { * } \\
\text { ヘクヘ背ク } \\
\text { ツレッ睪レ } \\
\text { ドペド音ペ } \\
\text { フリフのリ } \\
\text { オンオ負ン } \\
\text { ンのン荷開 } \\
\text { の説装開始 } \\
\text { 説明着始 } \\
\text { 明 }\end{array}$ & 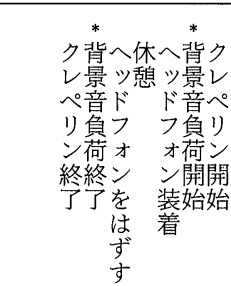 & 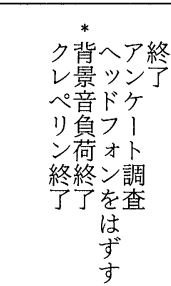 \\
\hline
\end{tabular}

* 背景音負荷時のみ

図 1 実験手順
背景音の負荷は, 以下のように行った。すなわ ち, 上記実験室で, 上記 CD ラジオカセットテープ レコーダーで再生した背景音を実験室内の 4 力所 に設置したコードレスヘッドフォンシステムから 送信した。各被験者は装着したコードレスヘッド フォンをとおして各々が受信した。なお音量につ いては，実験開始前に各被験者がヘッドフォンの 音量調節つまみで背景音楽として各自にとって好 ましい音量に調節するようにした，音量調節用の 音は音楽については実験で流す音楽と同じもの, ホワイトノイズの場合については刺激的音楽を約 20秒流している間に調整させた。実験場所は空の ない心理学実習室で，机，椅子の配列を同一にし て用い, 実験開始前に, 本実験と同様の機材と, 学生25名（本実験に参加しない学生）を配置し, 機材や着席位置による背景音の受信状況に差がな いことを確認した。

3）内田クレペリン精神検查の施行方法

内田クレペリン精神検查の方法は, 背景音負 荷・コントロールいずれの場合も, 既成の録音テー プ（内田クレペリン精神検查実施用号令テープ）* を用いて回答方法を指示しながら行った。

*註「内田クレペリン精神検查実施用号令テー プ」株式会社日本精神検査技術研究所

4）アンケート調查

各実験終了時に，実験に使用した背景音に対す る印象（快か・不快か，楽しかつたか・つまらな かったか，好きか・嫌いか，集中できたか・気が 散ったか, 疲れなかったか・疲れたか, 落ちつい たか・緊張したか）をアンケート（5段階法）に よって収集した。また最終回実験後に日常の音楽 聴取の習慣（日頃音楽をよく聴くか・聴かないか, 日頃どんな種類の音楽を聴くか, 勉強をしながら 音楽を聴くか・聴かないか）についてもアンケー 卜調查を行った。

\section{3. 統計解析}

1）内田クレペリン精神検査の結果の集計処理 各被験者の内田クレペリン精神検査の 1 分ごと の作業量を加算し，背景音負荷およびコントロー ルの前半・後半別に各群の平均值を算出し, 対応 
のあるものについては paired $\mathrm{t}$ 検定を行った. 誤 謬率についても同様の算出と検定を行った。また 3 群の背景音負荷およびコントロールにおける作 業量および誤謬率の比較は一元配置分散分析によ り行った。集計処理にはHALBAU の統計パッ ケージを用いた。

2）被験者の背景音に対する印象および日常の 音楽聴取習慣と内田クレペリン精神検查の結果と の関係の検討

背景音に対する被験者の印象および被験者の日 常の音楽環境と内田クレペリン精神検査の結果と の間に関係があるかを paired $\mathrm{t}$ 検定により検討 した.

\section{III 結 果}

集計に際しては，背景音負荷とコントロール両 方に参加した被験者 56 名を対象とした。刺激的音
楽を負荷した群は16名(刺激群と略称する)，鎮静 的音楽を負荷した群は19名（鎮静群と略称する）, ホワイトノイズを負荷した群は21名（ホワイトノ イズ群と略称する）であった。

1. 内田クレペリン精神検査の結果

1）作業量について（表 3, 図 2)

コントロールの前半・後半別平均作業量および 前半・後半別平均誤謬率の 3 群間の比較を一元配 置分散分析により行ったが，群間に差はなく 3 群 の構成員は均質であると考えられた。各群の背景 音負荷とコントロールとの作業量の比較を paired $t$ 検定により行ったところ，内田クレペリン精 神検査の特徴である練習効果（日本・精神技術研 究所，1973，中塚，1991）が全群にみられ，全て の群で背景音負荷に比較してコントロールの作業 量が多かった。 3 群の背景音負荷の作業量を一元 配置分散分析により比較したところ，刺激群，鎮

表 3 平均作業量の比較

\begin{tabular}{ccccrcr}
\hline & \multicolumn{2}{c}{ 刺激的音楽 $(\mathrm{N}=16)$} & \multicolumn{2}{c}{ 鎮静的音楽 $(\mathrm{N}=19)$} & \multicolumn{2}{c}{ ホワイトノイズ $(\mathrm{N}=21)$} \\
\cline { 2 - 7 } & 負荷 & CTL & 負荷 & CTL & 負荷 & CTL \\
\hline 前半 & $754.9 \pm 258.3$ & $910.6 \pm 285.7^{*}$ & $762.1 \pm 221.0$ & $930.3 \pm 216.6^{*}$ & $690.4 \pm 192.5$ & $852.7 \pm 225.9^{*}$ \\
後半 & $892.3 \pm 287.3$ & $988.1 \pm 292.7^{*}$ & $889.6 \pm 233.4$ & $1,013.2 \pm 244.3^{*}$ & $807.4 \pm 232.1$ & $909.1 \pm 231.7^{*}$ \\
\hline
\end{tabular}

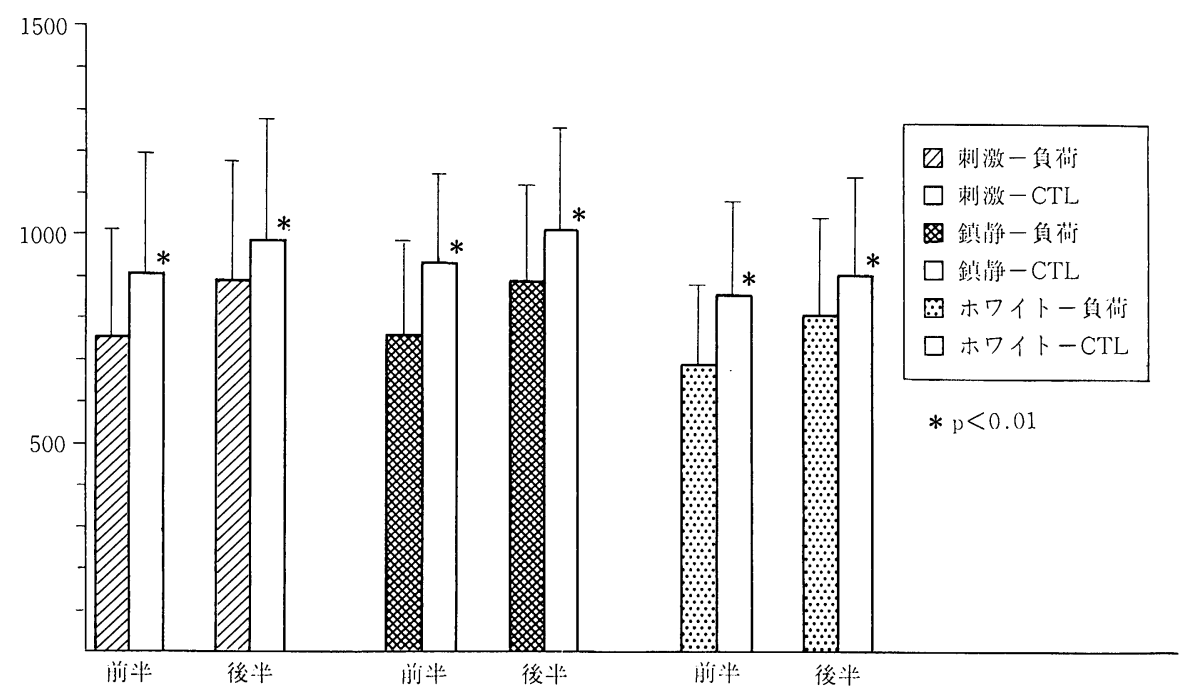

図 2 平均作業量の比較 
表 5 負荷した背景音に対する反応と検查結果(差があった項目)

\begin{tabular}{|c|c|c|c|c|}
\hline 背景音 & 質 問 & 項 目 & 肯定的な回答者 & 否定的な回答者 \\
\hline 鎮静的音楽 & 楽しかったか & 作業舀前半 & $814.80(15)$ & $564.50(4)^{*}$ \\
\hline 鎮静的音楽 & 落ちついたか & 作業量前半 & $806.69(16)$ & $524.33(3)^{*}$ \\
\hline ホワイトノイズ & 好きか & 作業基前半 CTL との差 & $-205.63(8)$ & $-135.54(13)^{*}$ \\
\hline ホワイトノイズ & 疲れなかったか & 作業量前半 CTL との差 & $-257.50(2)$ & $-152.21(19)^{*}$ \\
\hline 刺激的音楽 & 集中できたか & 誤謬率後半 CTL との差 & $0.23(12)$ & $1.21(4)^{*}$ \\
\hline 鎮静的音楽 & 心地よかったか & 誤謬率後半 CTL との差 & $-0.06(15)$ & $-1.02(4)^{*}$ \\
\hline 鎮静的音楽 & 疲れなかったか & 誤謬率後半 CTL との差 & $0.27(8)$ & $-0.65(11)^{*}$ \\
\hline
\end{tabular}

表 6 日常の音楽環境と検查結果(差があった項目)

\begin{tabular}{|c|c|c|c|c|}
\hline 背景音 & 問 & 項 目 & 䅡極的な回答者 & 消極的な回答者 \\
\hline 刺激的音楽 & 日頃聞く音楽 & 作業量前半 & $827.67(12)$ & $536.75(4)^{*}$ \\
\hline 刺激的音楽 & 日頃聞く音楽 & 作業量後半 & $978.17(12)$ & $634.75(4)^{*}$ \\
\hline 刺激的音楽 & 勉強しながら & 誤謬率前半 & $0.22(3)$ & $1.18(13)^{*}$ \\
\hline
\end{tabular}

肯定的な回答をした者でも，背景音負荷でコント ロールよりも作業量が少なかった。

2）日常の音楽聴取習慣とクレペリン精神検査 の結果（表 6)

被験者の日常の音楽聴取習慣が本実験にどのよ うに影響するかを知るために，音楽聴取習慣につ いて質問した。音楽を聞く習慣の頻度による差は 認められなかったが，日頃刺激的音楽をよく聞く 者では, 刺激的音楽負荷で前半・後半両方で作業 量が多かった.勉強しながら音楽を流さない者は, 刺激的音楽負荷で前半の誤謬率が高かった。

\section{IV 考 察}

内田クレペリン精神検査の作業量は, 意志緊張, 興儡, 慣熱, 練習, 疲労の 5 因子の影響を受けて 推移し，判定には作業曲線の型の他，数量化によ る方法（中塚，1991）などがある。誤謬は定型で はほとんどない（日本・精神技術研究所，1975） とされており，誤謬数の測定が疲労度測定などに 用いられている。本研究では，質問票調查におけ る背景音楽の効果を検証するために，各背景音負 荷とコントロールとの平均作業量および平均誤謬 率を背景音負荷およびコントロールに分けて検討
した. 休憩効果により後半の作業量が多い（日本・ 精神技術研究所，1973，中塚，1991）とされてい ることから，群ごとに休䅗をはさんだ前半・後半 別に算出した.

\section{3 群の構成員の均質性についての検討}

コントロールの作業量および誤謬率（表 5 ）の 比較で 3 群間に差が認められなかったことから， 内田クレペリン精神検査に関して 3 群の構成員は 均質であると考えた。

\section{2. 作業量および誤謬率に対する背景音の影響 についての検討}

背景音を負荷して行うクレペリン精神検査にお ける作業量の増加，誤謬率の減少は，背景音の効 果と考えることができる，逆に作業量の減少，誤 謬率の増加は，背景音に効果がないか，逆に作業 を阻害するものと考えられる。

1）作業量に対する刺激的音楽，鎮静的音楽，木 ワイトノイズの影響

まず背景音楽の影響についてみると，山松ら （1975）は，中学生では量的・質的に，高校生では 量的にのみ背景音楽の効果がみられ，大学生では 逆効果を示し背景音楽が作業を阻害すると述べて いる. 大場らは中学生を対象としたクレペリンに 
よる 2 桁かけ算による一連の実験を行い，背景音 楽には騒音を遮蔽する効果があり，男女ともに作 業能率の低い群に対して背景音楽は阻害的に作用 する(大場ほか, 1978a) という結果を示している. また背景音楽の騒音遮蔽の効果は, 音楽のテンポ によって異なり，早いテンポの曲は遅いテンポの 曲にくらべて騒音の遮蔽効果が弱い（大場ほか, 1979), リズムを中心とした音楽は 2 桁かけ算作業 に対する阻害効果は弱く，その阻害性は加齢とと もに計算能力の向上により消失する（川畑ほか, 1980), 旋律を中心とするテンポの遅い音楽は, 負 荷直後に顕著な阻害効果を与え，作業後半部では ほとんど効果をもたない（川畑ほか，1980）など の結果を示している，内田クレペリン精神検査の 作業量に対する騒音の影響については，前半に影 響がみられ個体差がある (Iwata，1975）との報告 があり，ホワイトノイズの影響に関しては，概し て阻害的に作用し, 低レベル群に阻害性が顕著で あり，作業開始直後の阻害性が著しい（大場ほか, 1976，川畑ほか，1980）との報告がある。しかし 筆者らの実験では, 内田クレペリン精神検査の作 業量においては，刺激的音楽，鎮静的音楽，ホワ イトノイズの間に影響の差はなく，女子短大生で は，背景音楽を負荷した場合でも，ホワイトノイ ズを負荷した場合でも作業量は影響を受けないと 考えられた。

2）誤謬率に対する鎮静的音楽の効果について の検討

Iwata は前出の論文 (Iwata，1975)において対 象によっては，静音下よりも騒音下において誤謬 が少なく，背景音の影響には個体差があることを 示唆している.川畑らは前出の報告（川畑ほか, 1980）で, 誤謬数は騒音時, 静音時の区別なく初 回が 2 回目に比して多かったとして, 誤謬数は騒 音の影響よりも練習効果の影響のみを受けると述 べている，しかし筆者らの実験では，刺激的音楽 およびホワイトノイズを負荷した場合には，誤謬 率において背景音としての影響がなく練習効果だ けがみられたが,鎮静的音楽を負荷した場合には， 練習効果を凌駕して音楽が正答率を高める影響を
及ぼすことが示唆された。

音楽には刺激的で人を活気づけるものと，心を 和らげ行動を穏やかにし静めるものとがある（山 松，1964）との前提から，刺激的音楽と鎮静的音 楽との 2 種類の音楽を背景音楽として用いて実験 を行ったが，内田クレペリン精神検査の作業量に 対しては, 阻害, 促進いずれの効果も示さなかっ た鎮静的音楽が，誤謬に関しては減少させる効果 を示したことから，鎮静的音楽が何らかの影響を 精神作用に対して及脑すものと考えられる。関連 する研究に，ロック音楽と，クラシック音楽を被 験者に負荷した時の脳波の変化をみた実験（辻， 1991，辻ほか, 1991)がある. 結果としてクラシッ ク音楽を負荷した時の脳波における $\alpha$ 波中心周 波数は，ロック音楽を負荷した場合よりも低く被 験者は「安静状態」にあったが，このような脳波 の周波数の変化の精神生理学的意味は明らかでな いとしている．緒方は音楽鑑賞時の脳波変動につ いて実験を行い（緒方，1989，緒方ほか，1991， Ogata, 1996), 受動的音楽鑑賞時に特徴的な心理 状態が内包されている（緒方ほか，1991）ことを 示唆し，ホワイトノイズを負荷した時にくらべる と,クラシック音楽鑑賞時の意識は覚醒から睡眠 への移行段階にありながら，被験者の注意力が高 い状態に維持されていた (Ogata，1996)ことを明 らかにしている．精神作用に対する音楽の影響の 機序については未だ不明な部分が多い（佐久間ほ か，1996）が，鎮静的音楽が知的作業における背 景音楽として効果的であり, 質問票調査において も有効であり得ることが示唆されたと考える.

\section{3. 背景音についての印象および日常の音楽聴 取の習慣と作業量・誤謬率との関係}

音楽の好き嫌いおよび慣れ不慣れ感と作業成績 との関係について大場は, 不慣れ感が強い群でも 有意な成績の低下は見られない（大場ほか，1978 a)との結果を示している. 本研究に扔いては, 使 用した背景音に対する印象について各実験終了時 に, 日常の音楽聴取の習慣について最終回実験後 に, アンケート調査を行って被験者の背景音につ いての印象および日常の音楽聴取の習慣と，各種 
の背景音負荷をした時の検査成績との間に関係が あるかどうかを検討した。

背景音の印象についてのアンケートへの回答 と, 内田クレペリン精神検查の結果との関連を検 討したところ，ホワイトノイズに対して否定的な 印象を持たなかった被験者でも，ホワイトノイズ が作業を阻害する要因となったことが推察され た。また背景音が作業の邪魔になったという印象 を持った鎮静群およびホワイトノイズ群で, 否定 的な回答をした群でも作業量・誤謬率に実際の影 響を受けてはいなかった，以上のことから背景音 楽に対する印象と内田クレペリン精神検査の結果 との関連はほとんどないが，ホワイトノイズに関 しては，印象が否定的でなくても作業を阻害する 可能性を否定することはできない. また背景音楽 としての刺激的音楽は, 日常の音楽聴取習慣の違 いによって異なる影響を及ぼす可能性が示唆され た.

\section{V まとめ}

質問票として内田クレペリン精神検査を用い, 3 種類の背景音を負荷した実験で以下の結果を得 た。

1. 刺激的音楽, 鎮静的音楽, ホワイトノイズの 3 種類の背景音が, 内田クレペリン精神検査の作 業量に対して及ぼす影響に差はみられなかった。

2. 鎮静的音楽は同検査の誤謬を減少せさる効 果があることが示唆された。

\section{VI 結語}

質問票調査を行う際の環境条件として，意図的 に背景音楽を負荷した場合の効果を検討するため に，2種類の音楽とホワイトノイズを負荷して内 田クレペリン精神検査を行う実験を行った。実験 の結果, 作業量については背景音の種類による影 響の差はみられなかったが, 誤謬率については, 鎮静的音楽が誤謬を減少させる影響として作用す ることが示唆された。質問票調査を行う際に, 調 查結果の安定化のために，音楽を積極的に負荷す る場合には, 音楽の種類としては, 鎮静的音楽が
適していると考えられた。

付記：本研究は, 平成 4 年, 5 年, 6 年度文部省科 学研究費補助金 (一般研究 B, 課題番号04454226研究 代表者豊川裕之）によるものの一部である.

謝辞：本論文をまとめるにあたり, 東邦大学公衆衛 生学教室豊川裕之教授に留切なご指導を頂いたことを 記し, 心からの感謝の意を表します. また共同研究者 でもあり，多々お世話になった同教室熊倉伸宏教授， 高柳満喜子講師, 西川浩昭助手, 城川美佳助手, 中谷 弥栄子助手に深く感謝いたします.

なお，背景音楽の選曲編集・録音の労をとって頂い たバイオミュージック学会前事務局長田中正道氏は平 成 5 年 7 月 10 日急逝されました。ここに表心より感謝 を捧げ，ご冥福をお祈りいたします。

\section{文献}

Iwata, O. (1975) : An analytical study on the effect of acoustic environment upon a continuous addition task, Japanese Psychological Research, 17(2), 61-71

大場義夫，丹 公雄 (1976)：騒音暴露下のクレペリ ン加算作業における一考察一白色 Noise 下での実 験一, 東京大学教育学部紀要, 15, 273-277

大場義夫, 川畑徹朗, 丹 公雄 (1978a)：騒音と B.G. M.が知的作業に及ぼす影響に関する実験的研究 (第 2 報)，東京大学教育学部紀要，17, 125-133

大場義夫, 川畑徹朗, 丹 公雄 (1978b)：騒音と B.G. M.が知的作業に及ぼす影響に関する実験的研究(第 3 報)，東京大学教育学部紀要，18, 133-144

大場義夫，川畑徹朗，丹 公雄 (1979)：騒音と B.G. M.が知的作業に及ぼす影響に関する実験的研究(第 4 報), 東京大学教育学部紀要, 19, 101-113

岡堂哲雄 責任編集 (1975)： 心理検査学, 心理アセス メントの基本, 垣内出版, 東京

緒方茂樹（1989）：音楽鑑賞時の脳波変動, 脳波と筋 電図, 17(1), 20-28

緒方茂樹, 柿沼日和（1991）：音楽鑑賞の精神生理学 的研究一楽曲がもつ音圧変動と意識状態一, Brain Science and Mental Disorders, 2(1), 309-315

Ogata, S. (1995) : Human EEG Responses to Classical Music and Simulated White Noise : Effects of a Musical Loudness Components on Consciousness, Perceptual and Motor Skills, 80, 779-790

柏木繁男（1975）：内田クレペリンにおける解析的評 価法, 金子書房, 東京

川畑徹朗, 丹 公雄, 大場義夫 (1980)：白色雑音が 内田クレペリン加算作業に及ぼす影響に関する実験 
的研究, 東京大学教育学部紀要, 20, 213-234

佐久間祐子，松井研一，梶山祥子，他（1996）：質問 票調査における音響環境の回答への影響について， 日本バイオミュージック学会誌, 14(2), 104-111

高木廣文 (1994)：HALBAU-4 マニュアル, 現代数学 社, 京都

滝本孝雄 (1993)：内田クレペリン精神作業検査, 心 理テスト入門, こころの科学増刊, 日本評論社, 東 京

武田 徹, 空井健三（1985）：内田クレペリン法の臨 床, 精神科 Mook, 10, 心理検査法, 金原出版, 東 京

过 陽一, 長沢一之, 系井 節 (1991)： 2 種類の音 楽鑑賞時における $\alpha$ 波周波数の比較, Brain Science and Mental Disorders, 2(1), 317-321

辻 陽一 (1991)：音楽刺激による $\alpha$ 波周波数と振幅 ゆらぎの変化，臨床脳波，33(9), 629-632

辻岡美延, 東村高良（1976）：内田クレペリン検査の 因子得点判定法と直感判定法との併存的妥当性, The Japanese Journal of Psychology, 46(6), 333341

中塚善次郎 (1991): 内田クレペリン検査の新評価法, 風間書房，東京
日本・精神技術研究所(編)（1973）：内田クレペリン 精神検査・基礎テキスト, 日本精神技術研究所, 東 京

野辺地篤郎 (1990)：鎮静的音楽・刺激的音楽, 日本 バイオミュージック研究会 (日本音楽療法協会)編, 音楽療法の理解, 日本バイオミュージック研究会, 東京

東村高良（1976）：内田・クレペリン検査の因子得点 判定法の因子的妥当性, The Japanese Journal of Psychology, 47(1), 31-39

松原達哉 編著（1996）： 心理テスト法入門，日本文化 科学社, 東京

山内一史, 楊箸隆哉, 他（1989）：暗算作業量に対す るカフェインの効果, 千葉大学看護学部紀要, 11,1 $-7$

山松質文 (1964)：ミュージックセラピー，音楽によ る心理療法, 岩崎学術出版社, 東京

ラドシーE., ルードルフ ボイル J. (1985)：音楽行動 の心理学 (徳丸吉彦, 他訳), 音楽の友社, 東京

渡辺茂夫（1992）：健康と音楽，ストレス時代を生き 抜くために，誠文堂新光社，東京

(受稿 1996.6.7；受理 1997.3.14) 